\title{
Temporal Characterisation of Ground-level Ozone Concentration in Klang Valley
}

\author{
Nur Izzah Mohamad Hashim ${ }^{1}$, Norazian Mohamed Noor ${ }^{1 *}$ and Sara Yasina Yusof ${ }^{1}$ \\ ${ }^{1}$ School of Environmental Engineering, Universiti Malaysia Perlis (UniMAP), Kompleks Pusat \\ Pengajian Jejawi 3, 02600 Arau, Perlis, Malaysia.
}

\begin{abstract}
In Malaysia, ground-level ozone $\left(\mathrm{O}_{3}\right)$ is one of the most significant air pollutants due to the increasing sources of ozone precursors. Hence, the surface $\mathrm{O}_{3}$ concentration should have received substantial attention because of its negative effects to human health, vegetation and the environment. In this study, hourly air pollutants dataset (i.e $\mathrm{O}_{3}$, Carbon monoxide $(\mathrm{CO})$, Nitrogen dioxide $\left(\mathrm{NO}_{2}\right)$, Particulate matter $\left(\mathrm{PM}_{10}\right)$, Nonmethane hydrocarbon $(\mathrm{NmHC})$, Sulphur dioxide $\left(\mathrm{SO}_{2}\right)$ ) and weather parameters (i.e. wind speed (WS), wind direction (WD), temperature (T), ultraviolet B (UVB)) for ten years period (2003-2012) in Klang Valley were selected for analysis in this study. Two monitoring stations were selected that are Petaling Jaya and Shah Alam. The aim of the study is to determine the diurnal variations of $\mathrm{O}_{3}$ concentrations according to the seasonal monsoon and the correlation between the ground-level $\mathrm{O}_{3}$ concentration and others parameter. A high concentration of ground-level $\mathrm{O}_{3}$ was observed during the first transition (April to May) for both of the stations. While at a low surface, $\mathrm{O}_{3}$ concentration was found out during the southwest monsoon within June to September. Pearson correlation was used to find the correlation between the $\mathrm{O}_{3}$ concentration and all other pollutants and weather parameters. Most of the relationship between $\mathrm{O}_{3}$ concentrationswas positively correlated with $\mathrm{NO}_{2}$ and negative relationship was found out with NMHC. These results were expected since these pollutants are known as the $\mathrm{O}_{3}$ precursors. Besides that, $\mathrm{O}_{3}$ concentration and its precursors show a positive significant correlation with all meteorological factors except for relative humidity.
\end{abstract}

\section{Introduction}

Tropospheric ozone $\left(\mathrm{O}_{3}\right)$ is an important atmospheric constituent because it plays a main role as both an oxidant and a greenhouse gas $[1,2]$. Most of the $\mathrm{O}_{3}$ concentrations occupy in ozone layer; which is located in the middle of the stratosphere and acts as a protecting shield that protects Earth from any harmful radiation. However, a small concentration of $\mathrm{O}_{3}$ also exists in the troposphere.

At the surface or ground level, ozone $\left(\mathrm{O}_{3}\right)$ is a secondary air pollutant that created by chemical reaction that occurs in atmosphere which give harmful effects on human health,

\footnotetext{
*Corresponding author: norazian@unimap.edu.my
} 
crop production, material quality, and the ecosystem [3,4]. This is the primary cause why the presence of $\mathrm{O}_{3}$ is becoming a severe environmental problem because it is hard to control and predict [5]. Besides that, ozone is unique among pollutants because it is not directly emitted by combustion processes or any other sources of air pollutants but it is formed photochemically from the sunlight-initiated oxidation of volatile organic compounds (VOCs) in the presence of nitrogen oxides (NOx) in the atmosphere [6]. Collectively, NOx and VOCs are referred to as ozone precursors [7]. In addition, ozone concentrations are strongly correlated to meteorological conditions. Therefore, to predict the concentration of surface ozone, the researchers must have good understanding not only on ozone itself but also the situation that make a contribution to its formation. In Malaysia, ground level ozone $\left(\mathrm{O}_{3}\right)$ becomes one of the most significant air pollutants due to the increasing sources of ozone precursors [8]. It was proved to negatively impact the air quality status around the world due to the growth in population and rapid development. It arises from natural sources (e.g., vegetation), mobile sources (e.g., motor vehicles), and stationary sources (power plants, industrial facilities, residential and commercial establishments).

Therefore, the study of surface ozone is important due to its long-term and short-term impacts on human health, well-being, vegetation and the environment when its exposure to the high ozone concentration $[9,10,11]$. Thus, to predict the ozone concentration, it is important to apply a model that describes the relationships within the ozone concentrations and many variables that cause its production. It is necessary and quite urgent to gain a good understanding of the characteristics of $\mathrm{O}_{3}$ pollution. Hence, the modeling of ozone's fluctuations provides the good prediction model. The outcomes from the analysis can be used to the next analysis such as principle component analysis (PCA) and developing the air pollution model that can be used to give early warning to the public in the future in Malaysia.

\section{Materials and methods}

In this research, the measured records of hourly air pollutants (i.e. $\mathrm{O}_{3}, \mathrm{CO}, \mathrm{NO}_{2}, \mathrm{PM}_{10}$, $\mathrm{NMHC}$, and $\mathrm{SO}_{2}$ ) and meteorological parameters (i.e. WS, WD, T, and UVB) in Klang Valley, Malaysia was chosen. In this research, two sites were selected namely Petaling Jaya and Shah Alam. All the hourly $\mathrm{O}_{3}$ concentration and meteorological data from 2003 to 2012 were provided by Department of Environment (DoE) Malaysia. These data were regularly subjected to quality control due to the high level of $\mathrm{O}_{3}$ concentration were released or emitted in atmosphere during that particular time. All of these data were sorted by locations, years, month, and day for analysis purposes.

\subsection{Study area and data collection}

Air quality data were obtained from two stations located at the Klang Valley. Petaling Jaya and Shah Alam monitoring stations were chosen due to the consistency of showing high frequency of higher $\mathrm{O}_{3}$ concentration if compared to the DOE standard, which are 0.06 ppm ( 8 -h average) and $0.1 \mathrm{ppm}$ (1-h average). Besides that, these two areas were suggested to be selected due to the heavily industrialized area with high pollution, with a population of more than half a million, and high traffic density. Ten years of ground level ozone concentration from 2003 to 2012 were obtained from air quality monitoring in these stations. The data were owned by Department of Environment (DOE) Malaysia, however are managed by Alam Sekitar Malaysia Sdn. Bhd.

The monitoring station for Shah Alam is located at Sekolah Kebangsaan Taman Tun Dr Ismail Jaya, with the coordinate of $\mathrm{N} 3.1066^{\circ}$ and $\mathrm{E} 101.5573^{\circ}$. This station is located in 
residential areas and close to the industrial zone. While, the monitoring station in Petaling Jaya is located in Sekolah Menengah Kebangsaan Bandar Utama (N 3.1315, E 101.6082). This station is located in a housing area and beside the Jalan Utara (road) and light industrial area. This station was surrounded by residential, commercial, light industrial and green areas.

\subsection{Data analysis}

The aim of the study was to determine the diurnal variations of $\mathrm{O}_{3}$ concentrations according to the monsoon and also the correlation between ground level $\mathrm{O}_{3}$ concentration with others parameter. Hence, all of these data were sorted by locations, years, month, and day for the analysis. After that, the hourly and diurnal data of ground level ozone concentration were examined visually using diurnal plot and Pearson correlation.

Correlation is a measure of association between two variables. Pearson correlation is one of the correlation is reported by ' $r$ ' and it is used to determine the strength of a linear relationship between two variables. Thus, the relationship between ozone, pollutant and meteorological parameter are being investigated by using this correlation. In this study, the Pearson correlation was conducted to determine the relationship between different air pollutants at each station as well as the connection between $\mathrm{O}_{3}$ concentration and meteorological factors, such as temperature, wind speed and humidity.

\section{Results and discussions}

\subsection{Monthly diurnal plot}

Fig. 1 shows the monthly diurnal plot of surface $\mathrm{O}_{3}$ concentration in Petaling Jaya and Shah Alam. The surface $\mathrm{O}_{3}$ concentration were plotted according to the four (4) dominant monsoon throughout a year. Malaysia annually experiences four distinct monsoonal changes, there are the Northeast Monsoon (NEM), the First Transition ( $1^{\text {st }}$ transition), the Southwest Monsoon (SWM) and the Second Transition ( $2^{\text {nd }}$ transition). NEM occurs during early November and ends in March, while $1^{\text {st }}$ transition occurred from April to May. SWM occurred during Jun to September and $2^{\text {nd }}$ transition are in October. The northeast monsoon brings heavy rainfall to the country between November to January; while February to March usually associated with hot weather. The southwest monsoons mainly bring hot and dry weather from June to September. However, during the two transitions monsoon, the winds are generally light and variable [12].

Overall, from the plot, the highest concentrations of ozone were observed during the transition monsoon ( $2^{\text {nd }}$ intermonsoon $)$ due to the high penetration of light and variable wind speed. However, the highest $\mathrm{O}_{3}$ concentration was recorded during the transition monsoon, followed by the northern-east monsoon, and the southern-west monsoon respectively.From this result, it also shows the average diurnal profiles of $\mathrm{O}_{3}$ concentration for both dry and wet season shows almost the same pattern that suggested the $\mathrm{O}_{3}$ concentrations had lower concentration compared to the transition monsoon. Normally in the inter-monsoon (wet season) it was supposed to have lower pollutant concentration due to the precipitation of rain that will carry the pollutants to the earth and can reduce the level of pollutants in the atmosphere [13]. 


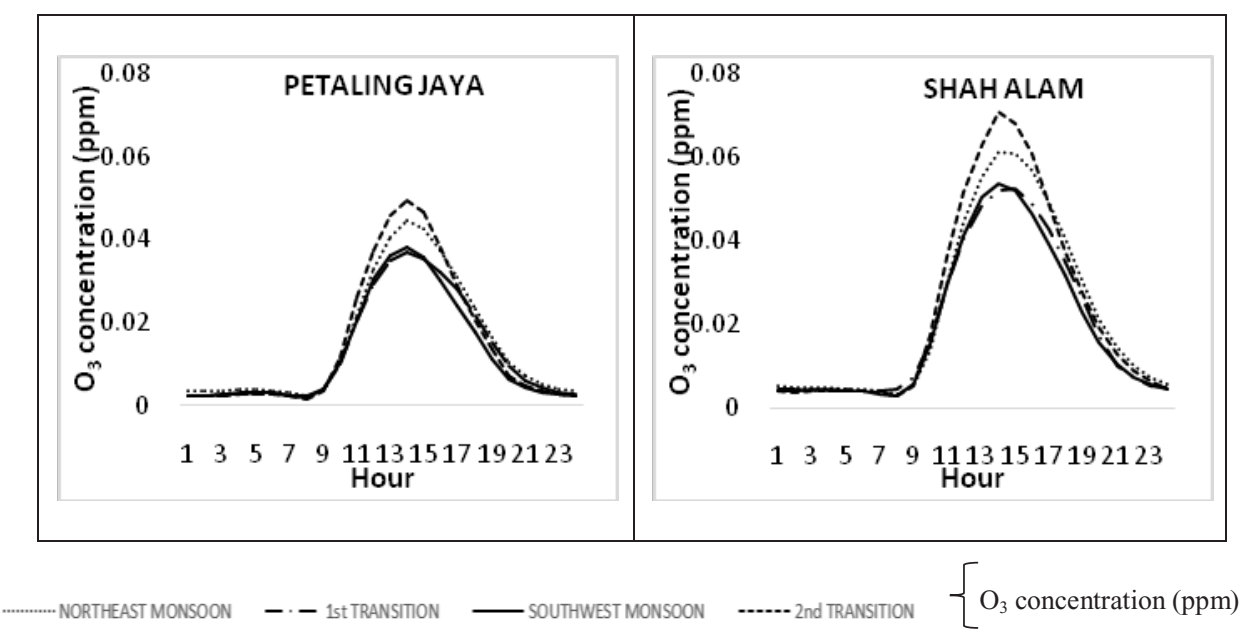

Fig. 1. Line graph of hourly average of ozone concentrations by monsoon.

\subsection{Correlations of air pollution and meteorological parameters}

Table 1 shows the Pearson correlation matrix of different variables for Petaling Jaya and Shah Alam during the peak concentration of $\mathrm{O}_{3}(1300-1600 \mathrm{pm})$. While, Fig. 2 shows the scatter plots for the highest correlated variables (from the results of Table 1) in these two locations. The relationships between pollutant-pollutant and pollutant-meteorological parameter are being investigated by using these correlations. These tables show that the correlation between $\mathrm{O}_{3}$ concentration with the wind speed (WS), wind direction (WD), temperature (T), ultraviolet (UVB), humidity $(\mathrm{H})$, non-methane hydrocarbons (NMHC), sulphur dioxide $\left(\mathrm{SO}_{2}\right)$, nitrogen dioxide $\left(\mathrm{NO}_{2}\right)$, carbon monoxide $(\mathrm{CO})$, and particulate matter $\left(\mathrm{PM}_{10}\right)$. These values show the correlation is significant at the 0.01 levels.

Mostly, the positive correlation was found out to be between $\mathrm{O}_{3}$ concentrationsand $\mathrm{NO}_{2}$, whereas, negative relationship was observed between $\mathrm{NMHC}$ and $\mathrm{O}_{3}$ concentration. This result was expected since these pollutants are known as precursors of $\mathrm{O}_{3}$. It indicates that high $\mathrm{O}_{3}$ concentration is associated with the low level of all these pollutants. Besides that, $\mathrm{O}_{3}$ concentration shows a positive significant correlation with all meteorological factors except for relative humidity. The precursors also have significantly negative relationships with all the meteorological factors except for relative humidity.

Fig. 2 shows that the highest correlated values for Petaling Jaya and Shah Alam. For Petaling Jaya, a positive correlation $(\mathrm{p}<0.01)$ between $\mathrm{SO}_{2}-\mathrm{CO}$ and $\mathrm{NO}_{2}$ which were valuated at $\left(r=0.611, r^{2}=0.3735\right)$ and $\left(r=0.731, r^{2}=0.535\right)$. While, the correlations are negative between Temperature $(\mathrm{T})$-Humidity $(\mathrm{H})$, which was $\left(\mathrm{r}=-0.750, \mathrm{r}^{2}=0.0 .5631\right)$. While, for Shah Alam, a significant negative correlation was observed between $\mathrm{T}-\mathrm{H}$, which was $\left(r=-0.860, r^{2}=0.7403\right)$ and positive correlation for $\mathrm{PM}_{10}-\mathrm{CO}\left(\mathrm{r}=0.637, \mathrm{r}^{2}=0.4058\right)$. 
Table 1: Pearson correlation matrix of different variables for Petaling Jaya and Shah Alam.

\begin{tabular}{|c|c|c|c|c|c|c|c|c|c|c|c|}
\hline PJ & WS & WD & $T$ & UVB & $\mathbf{H}$ & NMHC & $\mathrm{SO}_{2}$ & $\mathrm{NO}_{2}$ & $\mathrm{CO}$ & $\mathbf{P M}_{10}$ & $\mathrm{O}_{3}$ \\
\hline WS & 1 & 0.126 & 0.094 & & -0.239 & & $0 . \overline{214}$ & -0.388 & -0.361 & -0.119 & -0.050 \\
\hline WD & & 1 & 0.138 & & 0.033 & & 0.215 & 0.261 & 0.237 & 0.098 & -0.108 \\
\hline $\mathrm{T}$ & & & 1 & & -0.750 & & $0 . \overline{-}$ & -0.088 & -0.081 & 0.091 & 0.071 \\
\hline $\mathrm{H}$ & & & & & 1 & & 0.123 & 0.188 & 0.164 & -0.080 & -0.137 \\
\hline $\mathrm{SO}_{2}$ & & & & & & & 1 & 0.575 & 0.611 & 0.351 & \\
\hline $\mathrm{NO}_{2}$ & & & & & & & & 1 & 0.731 & 0.406 & \\
\hline $\mathrm{CO}$ & & & & & & & & & 1 & 0.544 & \\
\hline $\mathrm{PM}_{10}$ & & & & & & & & & & 1 & 0.091 \\
\hline $\mathrm{O}_{3}$ & & & & & & & & & & & 1 \\
\hline SA & WS & WD & $\mathbf{T}$ & UVB & $\mathbf{H}$ & NMHC & $\mathrm{SO}_{2}$ & $\mathrm{NO}_{2}$ & $\mathrm{CO}$ & $\mathrm{PM}_{10}$ & $\mathbf{O}_{3}$ \\
\hline WS & 1 & 0.132 & 0.047 & 0.139 & -0.058 & -0.176 & & -0.310 & -0.162 & & -0.057 \\
\hline WD & & 1 & -0.058 & 0.076 & 0.147 & -0.153 & 0.087 & -0.273 & -0.153 & -0.080 & 0.047 \\
\hline $\mathrm{T}$ & & & 1 & 0.592 & -0.860 & -0.130 & & -0.227 & & 0.135 & 0.130 \\
\hline UVB & & & & 1 & -0.531 & -0.265 & $\begin{array}{c}- \\
0.209\end{array}$ & -0.461 & -0.288 & -0.242 & 0.152 \\
\hline $\mathrm{H}$ & & & & & 1 & 0.166 & & 0.211 & & -0.142 & -0.161 \\
\hline NMHC & & & & & & 1 & 0.193 & 0.531 & 0.387 & 0.322 & \\
\hline $\mathrm{SO}_{2}$ & & & & & & & 1 & 0.330 & 0.090 & 0.180 & \\
\hline $\mathrm{NO}_{2}$ & & & & & & & & 1 & 0.439 & 0.279 & \\
\hline $\mathrm{CO}$ & & & & & & & & & 1 & 0.637 & 0.091 \\
\hline $\mathrm{PM}_{10}$ & & & & & & & & & & 1 & 0.147 \\
\hline $\mathrm{O}_{3}$ & & & & & & & & & & & 1 \\
\hline
\end{tabular}

*PJ- Petaling Jaya, SA- Shah Alam

\section{Conclusions}

In conclusion, from the hourly diurnal plot of $\mathrm{O}_{3}$ concentration in Petaling Jaya and Shah Alam, it can be summarized that during daytime $(8 \mathrm{am}-7 \mathrm{pm})$, the peak started to develop at 8.00 a.m. and reached a peak at 1 p.m. -4 p.m. and decreased after 4 p.m. However, the concentration of $\mathrm{O}_{3}$ during night-time was far lower than the daytime concentration due to the absence of photochemical reactions. This is because during night-time $\mathrm{O}_{3}$ concentration had lower concentration due to no titration and also the deposition [1]. For the correlation between ground level $\mathrm{O}_{3}$ concentration with others parameters, Pearson correlation was used in this study. Most of the relationship between $\mathrm{O}_{3}$ concentration with $\mathrm{NO}_{2}$ and $\mathrm{NMHC}$ were negatively correlated since these pollutions are known as precursors to $\mathrm{O}_{3}$ concentration, which indicates that they originated from vehicle exhaust. Besides that, $\mathrm{O}_{3}$ and its precursors show a positive significant correlation with all meteorological factors except for relative humidity. 


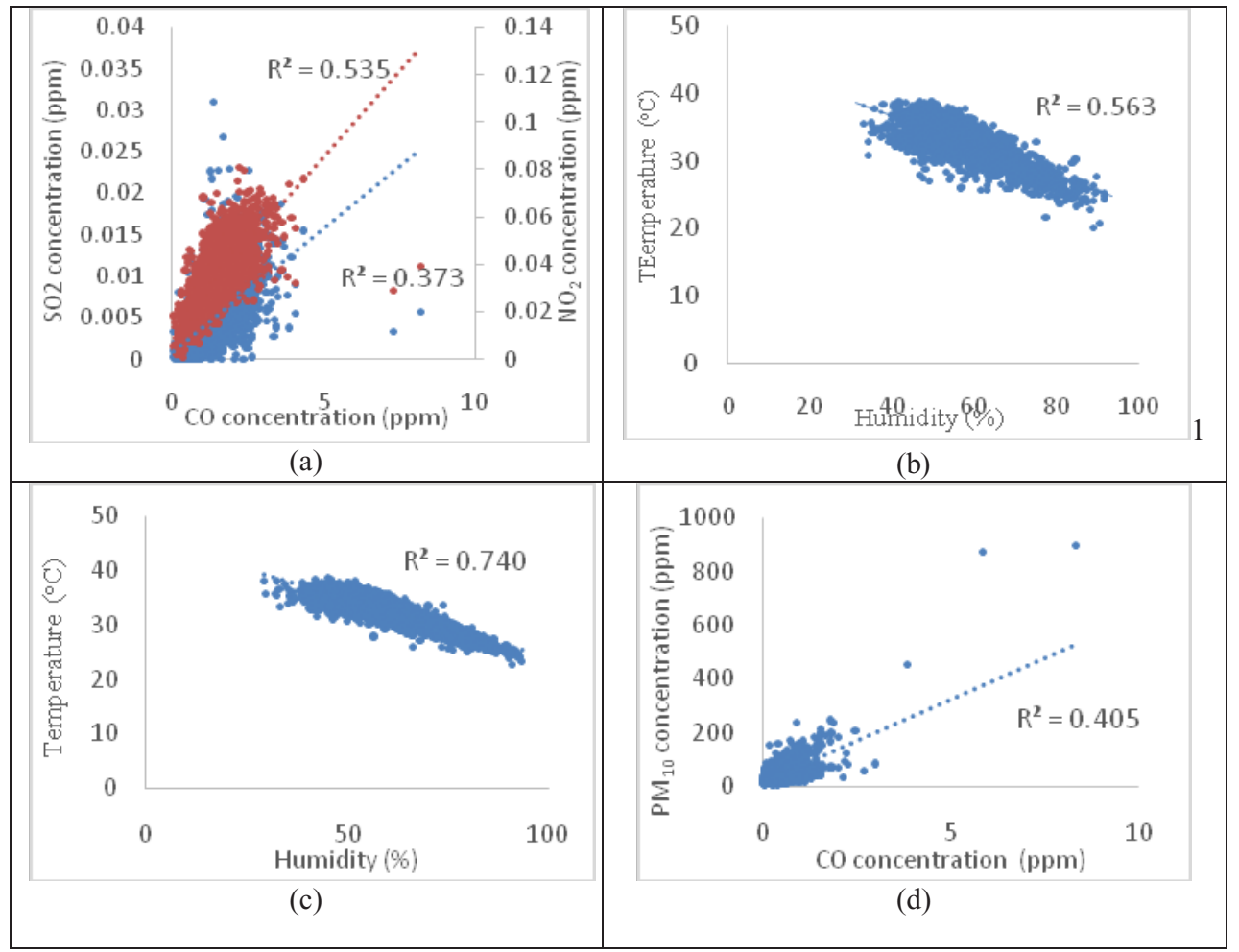

Fig. 2. Scatter plot of pollutants for the highest correlated values from Table 1. (a) \& (b) $=$ The most significant parameters in Petaling Jaya; (c) \& (d) = The most significant parameters in Shah Alam.

The authors would like to thank the Ministry of Higher Education Malaysia (MOHE) for the Fundamental Research Grant Scheme (FRGS 9003 00508) and the Department of Environmental (DOE) Malaysia for the air pollutants data.

\section{References}

1. N. R. Awang, N. A. Ramli, A. S. Yahaya, M. Elbayoumi, Aerosol Air Qual. Res. 15(4), 1357-1366 (2015)

2. Y. Ying, S. Fook, R. V. Glasow, Atmos. Environ. 70, 435-446 (2013)

3. T. Wang, L. Xue, P. Brimblecombe, Y. Fat, L. Li, L. Zhang, Sci. Total Environ. 575, 1582-1596 (2017)

4. K. C. Tan, H. San Lim, M. Z. M. Jafri, Atmos. Poll. Res. 1-14, (2016)

5. S. A. Abdul-Wahab, C. S .Bakheit, S. M. Al-Alawi, Environ. Modell. Softw. 20, 1263 $1271(2005)$

6. N. R.Awang, A.Ramli, N. I. Mohammed, A. S. Yahaya, International Journal of Engineering and Technology 3(3), 390-394, (2013)

7. S.A.Abdul-Wahab, C.S. Bakheit, S.M. Al-Alawi, Environ. Modell. Softw. 20, 12631271 (2005)

8. Air Quality Expert Group (AQEG). Ozone in the UK, the fifth report produced by air quality expert group, (Department for the Environment, Food and Rural Affairs. DEFRA publication London, 2009)

9. N. I. Mohammed, N. A.Ramli, A. S.Yahya, Atmos. Environ. 68, 343-349 (2013) 
10. B. R. Gurjar, T. M. Butler, M. G. Lawrence, J. Lelieveld, Atmos. Environ. 42, 15931606 (2008)

11. Ozden, T. Dogeroglu, S. Kara. Environ. Int. 34, 678-687 (2008)

12. S. A .Rahman, M. S.Hamzah, M. S. Elias, N. A. A. Salim, A. Hashim, S. Shukor, A. K. Wood. Aerosol Air Qual. Res. 15(6), 2291-2304 (2015)

13. Z. Syazwani,Application of GIS in Air Quality Monitoring of a Road Construction Project. (Universiti Teknologi Malaysia, Malaysia, 2010) 